\title{
Peningkatan Hasil Belajar PPKn melalui Model Time Token pada Peserta Didik Kelas V SD GMIT Ende 4
}

\author{
Maria Kewa ${ }^{1 *}$, Agustinus F. Paskalino Dadi ${ }^{2,}$, Adi Neneng Abdullah ${ }^{3}$ \\ 1,2,3 Program Studi PGSD Universitas Flores Ende \\ Jalan Sam Ratulangi, Kelurahan Paupire Kab. Ende Nusa Tenggara Timur \\ E-mail: dadiagustinus82@gmail.com
}

\begin{tabular}{|c|c|}
\hline Info Artikel & Abstract \\
\hline $\begin{array}{l}\text { Sejarah Artikel: } \\
\text { Diterima: } 20 / 03 / 2020 \\
\text { Direvisi: } 22 / 03 / 2020 \\
\text { Disetujui: } 25 / 03 / 2020\end{array}$ & $\begin{array}{l}\text { This research was motivated by the reality in 5th grade of SD Ende } 4 \text { GMIT which } \\
\text { includes: 1) the low learning outcomes of PPKn caused by learning processes was not } \\
\text { interesting, studentwere not active, and unseriousness students in learning; 2) learning } \\
\text { methods that tend to be teacher-centered so that students are less active in learning. The } \\
\text { purpose of this studv is to: 1) describe the application of the Time Token Learning Model }\end{array}$ \\
\hline $\begin{array}{l}\text { Keywords: Learning } \\
\text { Outcome, Time Token }\end{array}$ & $\begin{array}{l}\text { in the learning implementation plan and the mechanism of its implementation in learning } \\
\text { the PPKn at 5th grade of SD GMIT Ende 4; 2) describe the learning outcomes of students } \\
\text { in learning PPKn in 5th grade of SD Ende } 4 \text { GMIT after applying the Time Token } \\
\text { Learning Model. This method of research is a classroom action research study consisting } \\
\text { of } 2 \text { cycles, where each cycle applies Action Research Design by Kurt Lewin which } \\
\text { includes the stages of planning, implementing actions, observing and reflecting. The } \\
\text { method of data collection methods are tests, observations, interviews and document } \\
\text { studies. The results of this research is Time Token Model can improve the learning } \\
\text { outcomes of PPKn on 5th grade students of SD GMIT Ende 4. This is evidenced by the } \\
\text { average value of learning outcomes and the percentage of students completeness classical } \\
\text { after the Time Token Model is applied. At the time of the pretest, the average value of } \\
\text { PPKn learning outcomes was 53.57, with a classical completeness percentage is } 21.43 \% \text {. } \\
\text { This result has increased in first cycle with average value is } 69.64 \text { and the percentage of } \\
\text { classical completeness is 35.71\%. In second cycle, learning outcomes average value has } \\
\text { increased to 99, 28, with percentage of classical completeness is } 100 \% \text {. }\end{array}$ \\
\hline
\end{tabular}

\begin{abstract}
Abstrak
Penelitian ini dilatarbelakangi realitas di kelas V SD GMIT Ende 4 yang meliputi: 1) rendahnya hasil belajar PPKn yang disebabkan oleh proses pembelajaran yang kurang menarik, ketidakaktifan peserta didik, dan ketidakseriusan peserta didik dalam mengikuti pembelajaran; 2) metode pembelajaran yang cenderung berpusat pada guru sehingga peserta didik kurang aktif dalam pembelajaran. Tujuan penelitian ini adalah untuk: 1) mendeskripsikan penerapan model pembelajaran Time Token dalam Rencana Pelaksanaan Pembelajaran dan mekanisme pelaksanaannya di dalam pembelajaran PPKn kelas V SD GMIT Ende 4; 2) mendeskripsikan hasil belajar peserta didik pada pembelajaran PPKn di kelas V SD GMIT Ende 4 setelah menerapkan model pembelajaran Time Token. Jenis penelitian yang digunakan adalah penelitian tindakan kelas yang terdiri dari 2 siklus, di mana setiap siklus menerapkan desain penelitian tindakan model Kurt Lewin yang meliputi tahap perencanaan, pelaksanaan tindakan, observasi dan refleksi. Metode pengumpulan data yang digunakan adalah tes, observasi, wawancara dan studi dokumen. Hasil penelitian menunjukkan bahwa model Time Token dapat meningkatkan hasil belajar PPKn pada peserta didik kelas V SD GMIT Ende 4. Hal ini dibuktikan dengan nilai ratarata hasil belajar dan persentase ketuntasan klasikal peserta didik setelah diterapkan model Time Token. Pada saat pretest nilai rata-rata hasil belajar PPKn adalah 53,57 dengan persentase ketuntasan klasikal sebesar 21, $43 \%$. Hasil ini mengalami peningkatan pada siklus 1 dengan nilai rata-rata hasil belajar 69,64 dan persentase ketuntasan klasikal sebesar $35,71 \%$. Pada siklus 2 mengalami peningkatan hasil belajar dengan nilai rata-rata hasil belajar sebesar 99, 28 dan persentase ketuntasan klasikal sebesar $100 \%$.
\end{abstract}

\section{*Alamat korespondensi:}

Program Studi Pendidikan Guru Sekolah Dasar

Fakultas Keguruan dan Ilmu Pendidikan Universitas Flores

Kampus III Universitas Flores, Jln. Samratulangi,

Kelurahan Paupire, Ende, NTT

E-mail: dadiagustinus82@gmail.com
(C) 2020 Program Studi PGSD Universitas Flores Email: primagistrauniflor@gmail.com 


\section{PENDAHULUAN}

Pendidikan dan kehidupan manusia adalah dua entitas yang saling berkaitan. Manusia diciptakan secara istimewa dengan akal budi, perasaan dan kehendak namun semua itu hanya mungkin bertumbuh dan berkembang apabila ada pendidikan. Pendidikan membuat manusia mampu berpikir, mengolah rasa dan kehendak untuk berbuat sesuatu atas dasar pemikiran dan perasaannya itu. Pendidikan membantu manusia untuk menemukan segala potensi diri dan mengembangkannya untuk kehidupan saat ini dan pada masa yang akan datang. Pendidikan dapat membuat manusia memiliki kualitas diri yang memadai dan pada akhirnya dapat memenuhi tuntutan kehidupan yang mengharuskan adanya sumber daya manusia yang berkualitas tinggi.

Pendidikan dapat dilaksanakan dalam berbagai bentuk. Ada yang dapat dilakukan secara formal dan ada pendidikan yang bersifat non formal. Pendidikan formal menerapkan sistem dan mekanisme yang sangat teratur dan berjenjang dalam wadah sekolah, mulai dari pendidikan usia dini hingga pendidikan di perguruan tinggi. Pendidikan formal ini diharapkan mampu meningkatkan kualitas manusia secara utuh dan menyeluruh baik menyangkut pengetahuan, sikap maupun kemampuan psikomotoriknya sesuai dengan tingkat usia dan jenjang pendidikannya.

Inti dari pendidikan formal pada setiap jenjang pendidikan adalah pembelajaran di sekolah. Pembelajaran yang berkualitas adalah pembelajaran yang dilaksanakan dengan proses yang baik dan memberikan hasil yang baik berupa peningkatan kualitas pada diri peserta didik. Pembelajaran yang berkualitas tidak hanya ditentukan oleh satu komponen, tetapi mengandalkan kolaborasi antarkomponen seperti guru, peserta didik dan metode pembelajaran.

Guru seharusnya memiliki motivasi yang tinggi, kreatif dan inovatif dalam menerapkan model dan metode pembelajaran yang tepat, sesuai materi pembelajaran dan karakterisitik peserta didiknya. Guru harus mampu membuat pembelajaran terasa menarik dan menyenangkan bagi peserta didik, membuat peserta didik mampun untuk menggali dan mengembangkan segala potensi dirinya, dan secara aktif melaksanakan pembelajaran dengan memanfaatkan segala potensi yang dimilikinya itu. Guru seharusnya dapat membuat peserta didik merasa percaya diri untuk terlibat secara aktif di dalam pembelajaran, mengekspresikan dirinya, mengungkapkan pendapatnya secara bebas, dan bekerja sama dengan peserta didik lainnya dalam proses pembelajaran yang dilaksnakannya.

Pada titik yang lain, pembelajaran yang berkualitas juga harus ditunjukkan dengan adanya keterlibatan yang aktif dari peserta didik dan hasil belajar yang optimal sesuai harapan. Keterlibatan yang aktif ditandai dengan perilaku sikap peserta didik yang memberikan perhatian yang sungguh terhadap proses pembelajaran, aktif bertanya dan memberikan pendapat sesuai dengan pengetahuan dan kemampuan yang dimilikinya. Keaktifan ini kemudian menjadi senjata yang ampuh untuk meningkatkan hasil belajar secara optimal sesuai dengan harapan dan tujuan pembelajaran. Pembelajaran yang berkualitas hanya dapat dirumuskan oleh guru 
dalam bentuk pilihan metode dan model pembelajaran yang tepat (Silberman, 2009:22) berbasis karakteristik peserta didik, materi pembelajaran dan kompetensi dasar yang mau dicapai di dalam pembelajaran tersebut.

Pembelajaran yang baik dan berkualitas harus juga didukung dengan kecocokan antara metode atau model pembelajaran dan materi pembelajaran. Metode atau model yang tepat dapat membuat peserta didik termotivasi untuk belajar dan dapat mengoptimalkan hasil belajar yang diperoleh peserta didik.

Harapan ini tentunya perlu dikomparasikan dengan kenyataan yang dijumpai dalam proses pembelajaran di setiap jenjang pendidikan. Apakah realitas telah menunjukan adanya pencapaian dari harapanharapan tersebut? Sanjaya (2014: 34) mengatakan bahwa secara empiris rendanya hasil belajar peserta didik disebabkan oleh pembelajaran yang masih bersifat konvensional dan belum menyentuh ranah peserta didik. Proses pembelajaran didominasi oleh guru dan tidak memberikan akses bagi peserta didik untuk berkembang secara mandiri melalui penemuan dalam proses berpikir sehingga menyebabkan peserta didik menjadi pasif. Peserta didik yang pasif adalah peserta didik yang dijadikan sebagai objek, bukan sebagai subjek (Wulan, dkk., 2016). Akibatnya hasil belajar yang diperoleh pun kurang maksimal.

Berdasarkan hasil pengamatan, wawancara dengan kepala sekolah dan guru, serta studi pendahuluan terhadap data hasil belajar peserta didik kelas V SD GMIT Ende 4, ditemukan adanya fakta yang agak menyimpang dari harapan-harapan tersebut. Hasil belajar peserta didik kelas V SD GMIT
Ende 4 dalam pembelajaran PPKn ternyata belum sesuai harapan. Hal ini terlihat pada nilai hasil belajar PPKn peserta didik kelas V yang diketahui hanya mencapai nilai rata 68,5 dengan persentase ketuntasan klasikal sebesar $54 \%$. Nilai ini masuk dalam kategori rendah.

Kondisi hasil belajar ini tentunya memiliki sebab tersendiri. Setelah ditelaah secara cermat, sdari rendahnya hasil blajar tersebut adalah penggunaan metode pembelajaran yang diterapkan oleh guru. Guru berpandangan dirinya memiliki pengetahuan yang lebih luas dari peserta didik tentang materi pembelajaran PPKn sehingga metode pembelajaran yang dilaksanakan lebih terpusat pada dirinya. Peserta didik hanya dibiarkan mendengar dan mencatat materi yang dijelaskan oleh guru. Guru tampil sangat dominan di hadapan peserta didik, berbicara dan membuat penjelasan yang panjang sementara peserta didik hanya mendengar dengan sikap yang pasif tanpa mencermati tingkat pemahaman peserta didik terhadap materi yang dijelaskan.

Kondisi hasil rendahnya hasil belajar dan kekuragaktifan peserta didik di dalam pembelajaran merupakan masalah yang harus segera dibenahi dengan upaya pembenahan yang efektif dan efisien. Metode pembelajaran yang tidak mengaktifkan peserta didik dan tidak membuat hasil belajar yang tinggi pada peserta didik harus diganti. Salah satu model yang dapat ditawarkan adalah model Time Token.

Arends (1997:137) mengungkapkan bahwa model Time Token dapat menciptakan pemerataan peran peserta didik di dalam aktivitas pembelajaran kooperatif dan menghindarkan peserta didik dari dominasi peserta didik tertentu atau diam sama sekali, 
serta memotivasi peserta didik untuk saling membantu dalam kelompok kecil. Model pembelajaran Time Token memberikan ruang bagi masing-masing anggota kelompok diskusi untuk memberikan konstribusi dalam menyampaikan pendapat mereka dan mendengarkan pandangan serta pemikiran anggota lain (Arends, 1998:37). Model ini diharapkan dapat mengatasi permasalahan peserta didik yang kurang aktif selama pembelajaran berlangsung, baik dalam diskusi kelompok maupun klasikal serta dapat mengurangi peserta didik yang mendominasi dan menagktifkan peserta didik yang yang bersikap diam (Istarani, 2011; Suprijono,2013; Sukmayati, 2014; Wulan, dkk., 2016). Model Time Token dalam pembelajaran PPKn memungkinkan guru untuk menerapkan pembelajaran yang menyenangkan, mengesankan dan dapat memicu partisipasi aktif dari peserta didik, sehingga keaktifan peserta didik dapat meningkat serta peserta didik dapat berlatih belajar mandiri, aktif, dan kreatif (Huda, 2013:239). Penataan peran ini mengingat bahwa pada umumnya peserta didik dalam suatu kelas belajar, memiliki sekelompok kecil peserta didik yang mendominasi percakapan dan ada sejumlah peserta didik yang malu dan tidak pernah berbicara sama sekali.

Selain dasar teoretis di atas, hasil penelitian yang telah dipublikasikan juga menunjukkan bukti bahwa model Time Token adalah model yang ideal untuk mengatasi problem aktivitas dan hasil belajar yang tidak optimal. Model Time Token terbukti dapat a) meningkatkan kemampuan berbicara peserta didik kelas XI SMA Laboratorium Unsyah (Sukmayati, 2014), b) meningkatkan hasil belajar Biologi pada peserta didik Kelas XI SMAN 5 Banda Aceh (Wulan, dkk., 2016), c) meningkatkan pemahaman konsep matematika pada peserta didik kelas VIII SMP Negeri 3 Pasir Penyu Riau (Beni dan Novita, 2018), d) meningkatkan hasil belajar IPS pada peserta didik kelas V SD Negeri Pejambon (Nunu dan Hidayatuloh, 2018), e) meningkatkan aktivitas belajar sejarah pada peserta didik Kelas X SMAN 1 Seputih Mataram Lampung (Siti, dkk., 2014).

Berdasarkan problem yang ditemukan di SD GMIT Ende 4 dalam pembelajaran PPKn dan dukungan hasil penelitian tentang keunggulan model Time Token, maka ditawarkan penggunaan Model Time Token untuk menyikapi problem itu. Tujuan yang diharapkan adalah penggunaan Model Time Token ini dapat meningkatkan keaktifan belajar dan hasil belajar peserta didik kelas $\mathrm{V}$ SD GMIT Ende 4 dalam pembelajaran PPKn Tahun Ajaran 2019/2020

\section{METODE PENELITIAN}

Penelitian ini menggunakan jenis Penelitian Tindakan kelas (PTK) dengan maksud untuk meningkatkan kualitas peran dan tanggung jawab guru dalam pengelolahan pembelajaran (Sanjaya, 2014:13). Penelitian tindakan kelas ini mengacu pada model penelitian tindakan kelas dari Kurt Lewin (Suharsimi, 2010:138) dengan skema sebagai berikut:

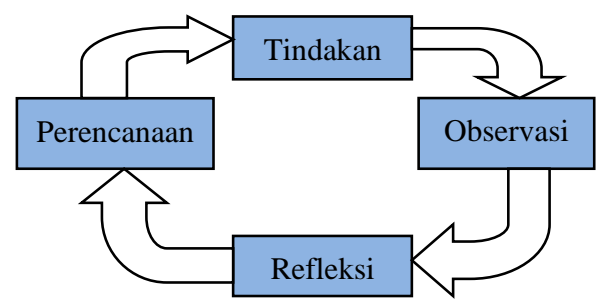

Gambar 1. Bagan Penelitian Tindakan Model Kurt Lewin (Sanjaya, 2014:50) 
Penelitian ini dilaksanakan pada bulan Juli 2019 di SD GMIT Ende 4 dengan subyek penelitian adalah peserta didik kelas VA Tahun Ajaran 2019/2020. Teknik pengumpulan data yang digunakan adalah tes, observasi, wawancara dan studi dokumen. Analisis data disesuaikan dengan jenis data yang dikumpulkan. Data hasil observasi dianalisis dengan analisis nilai aktivitas belajar peserta didik dan guru, menggunakan rumus dan kategori penilaian sebagai berikut:

$$
\mathrm{AB}=\frac{2 x}{Y} \mathrm{X} 100
$$

Tabel 1

Kategori Nilai Aktivitas Guru dan Peserta Didik

\begin{tabular}{ccc}
\hline No & Tingkat Keberhasilan & Kriteria \\
\hline 1 & $81-100$ & Sangat Tinggi \\
2 & $61-80$ & Tinggi \\
3 & $41-60$ & Rendah \\
4 & $<41$ & Sangat Rendah \\
\hline
\end{tabular}

Data yang diperoleh dengan teknik tes dianalisis dengan mengukur nilai akhir peserta didik menggunakan rumus:

Nilai Hasil Belajar $=\frac{\text { skorperolehan siswa }}{\text { skormaksimal }} \times 100$

dan persentase klasikal hasil belajar dengan rumus dan kategori sebagai berikut: $\mathrm{KK}=\frac{\text { Jumlah siswa yang memenuhi KKM }}{\text { jumlah siswa seluruhnya }} \times 100 \%$

Tabel 2

Kategori Persentase Ketuntasan Klasikal

\begin{tabular}{ccc}
\hline No & $\begin{array}{c}\text { Persentase } \\
\text { Ketuntasan }\end{array}$ & Kriteria \\
\hline 1 & $81 \%-100 \%$ & Sangat Tinggi \\
2 & $61 \%-80 \%$ & Tinggi \\
3 & $41 \%-60 \%$ & Rendah \\
4 & $<41 \%$ & Sangat Rendah \\
\hline
\end{tabular}

\section{HASIL DAN PEMBAHASAN}

\section{Deskripsi Awal}

Pelaksanaan penelitian di SD GMIT Ende 4 Kecamatan Ende Utara Kabupaten Ende dilaksanakan tanggal 16 Juli hingga 2 Agustus 2019, dengan subyek penelitian peserta didik kelas V/A yang berjumlah 28 orang (laki-laki 15 orang dan perempuan 13 orang). Berdasarkan hasil studi pendahuluan ditemukan adanya problem rendahnya aktivitas belajar dan hasil belajar peserta didik dalam pembelajaran PPKn. Hal ini memacu guru untuk menciptakan pembelajaran yang berkualitas, menarik, efektif dengan menggunakan model pembelajaran yang sesuai yaitu model Time Token.

Penelitian tindakan kelas dilakukan dengan orientasi pada peningkatan aktivitas belajar dan hasil belajar peserta didik saat mengikuti pembelajaran PPKn materi sikap-sikap yang sesuai dengan nilai-nilai yang terkandung dalam sila Pancasila.

\section{Deskripsi Data Hasil Tindakan}

Sebelum pelaksanaan tindakan dengan menggunakan model pembelajaran Time Token, rata-rata hasil belajar PPKn materi sikap-sikap yang sesuai dengan nilai-nilai yang terkandung dalam sila Pancasila semester I kelas V SD GMIT Ende 4 adalah 53,57. Kondisi ini dipandang sebagai akibat dari rendahnya tingkat keaktifan belajar peserta didik. Rendahnya hasil belajar peserta didik oleh pembelajaran yang bersifat monoton, satu arah, kurang komunikatif, serta sikap pasif dari peserta didik.

Model pembelajaran Time Token diharapkan mampu meningkatkan keterlibatan aktif peserta didik sehingga berimbas pada 
hasil belajar yang memuaskan. Time Token diharapkan dapat meningkatkan kemampuan berpikir dan kemampuan mengungkapkan pendapat dari peserta didik.

Sebelum pelaksanaan tindakan dengan model Time Token, dibuat pre-test untuk mengukur pemahaman peserta didik. Hasil pre-test menunjukkan bahwa 6 orang peserta didik tuntas dengan persentase ketuntasan sebesar $21,43 \%$, sedangkan 22 peserta didik masuk kategori tidak tuntas dengan persentase 78,57\%. Jumlah nilai pre-test adalah 1500 dengan rata-rata nilainya 53,57. Hasil pre-test dapat dilihat dalam grafik berikut:

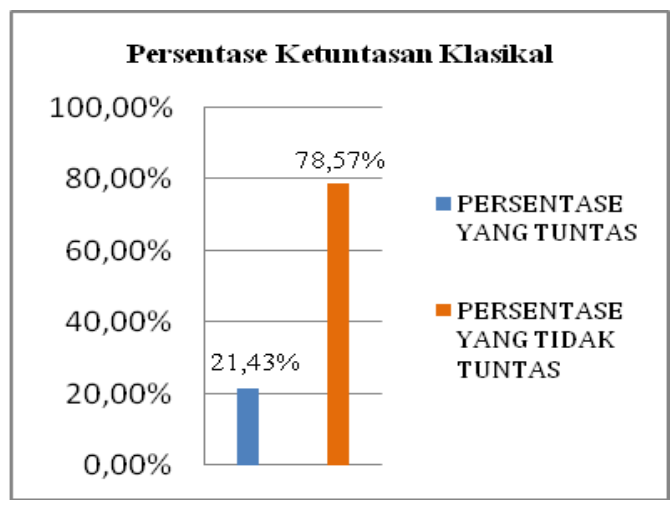

Gambar 2. Grafik Hasil Pre-Test

Setelah melakukan pre-test dan mengukur hasil dari pre-test, kemudian dilakukan tindakan untuk tahapan siklus yang pertama yang dilanjutkan ke siklus yang kedua. Masing-masing siklus terdiri atas empat tahap yakni perencanaan, tindakan, observasi dan refleksi.

\section{Siklus I}

\section{Perencanaan}

Tahap ini berisi kegiatan mencermati Rencana Pelaksanaan Pembelajaran (RPP) dan mendiskusikan langkah-langkah kegiatan pembelajaran bersama guru kelas $\mathrm{V}$, serta materi yang mau dipelajari. Perencanaan juga ditandai dengan aktivitas menyiapkan perlengkapan pembelajaran, menentukan sumber belajar berupa buku pegangan dan lembaran kerja peserta didik (LKS), menyiapkan media atau alat peraga yang dibutuhkan dan menyiapkan dokumen assesment untuk membuat evaluasi pembelajaran. Diskusi peneliti dan guru dalam tahap ini menghasilkan kesepakatan bahwa penelitian ini akan dilakukan secara kolaboratif antara guru kelas dan peneliti. Peneliti akan menjadi pelaksana utama tindakan (guru) dan guru kelas $\mathrm{V}$ membantu sebagai observer.

\section{Pelaksanaan}

Pada tahap ini peneliti yang berperan sebagai pelaksana pembelajaran (guru) melakukan aktivitas pembelajaran dengan menggunakan model Time Token. Pembelajaran dilaksanakan pada hari Senin tanggal 16 Juli 2019 di kelas V/A SD GMIT Ende 4. Pada tahap ini peneliti melaksanakan kegiatan pembelajaran dengan mengacu pada tahapan kegiatan pembelajaran model Time Token yang telah dibuat dalam RPP. Beberapa kegiatan utama dalam pembelajaran Time Token ini adalah peserta didik mendiskusikan materi yang dipelajari dan melaporkan hasil diskusinya, guru membagikan kartu berisi pertanyaan kepada setiap peserta didik, dan setiap peserta didik akan ditunjuk secara acak oleh guru untuk memberikan jawaban atas pertanyaan yang tertera di dalam kartu yang dibagikan kepadanya.

\section{Pengamatan}

Kegiatan pengamatan ini dilakukan oleh guru kelas selama proses pembelajaran berlangsung. Pengamatan dilakukan terhadap aktivitas peserta didik untuk mengukur nilai aktivitas belajar peserta didik dan aktivitas 
guru untuk mengukur terlaksananya penerapan model Time Token berdasarkan RPP. Hasil observasi menunjukkan bahwa pada saat proses pembelajaran, peserta didik mulai terlibat aktif dalam proses pembelajaran meskipun nilai aktivitasnya masih tergolong rendah. Nilai aktivitas belajar peserta dididik mencapai angka 54,24 dengan kriteria rendah. Hasil observasi aktivitas belajar peserta didik tersaji dalam grafik berikut:

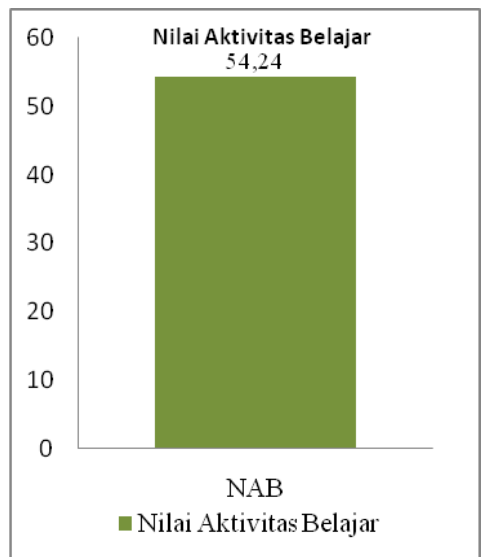

Gambar 4. Grafik Nilai Aktivitas Belajar Peserta Didik Siklus I

Hasil observasi terhadap aktivitas guru pada siklus I menunjukkan nilai aktivitas sebesar 66,67 dengan kriteria tinggi namun berada pada skor minimal untuk kategori tersebut. Nilai aktivitas guru dapat dilihat dalam grafik berikut:

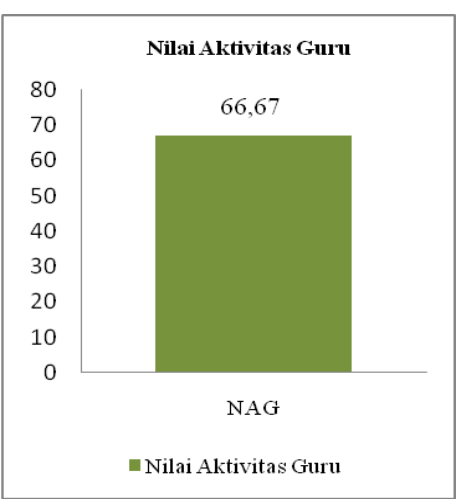

Gambar 5. Grafik Nilai Aktivitas Guru Siklus I

Selain pengamatan terhadap aktivitas belajar peserta didik dan aktivitas guru, dilakukan juga analisa terhadap hasil belajar peserta didik. Nilai hasil belajar peserta didik diperoleh melalui kegiatan tes setelah pembelajaran. Berdasarkan hasil tes pada siklus I diketahui bahwa hasil belajar peserta didik, dengan komposisi 10 orang tuntas $(35,71 \%)$ dan 18 orang tidak tuntas $(64,29 \%)$. Nilai rata-rata hasil belajar pada siklus 1 adalah 69,64. Hasil ini menunjukkan bahwa persentase ketuntasan klasikal hasil belajar telah mengalami peningkatan dari hasil pretest namun belum signifikan dan persentase ketuntasan klasikal masih tergolong rendah. Data hasil belajar dapat dilihat pada grafik berikut:

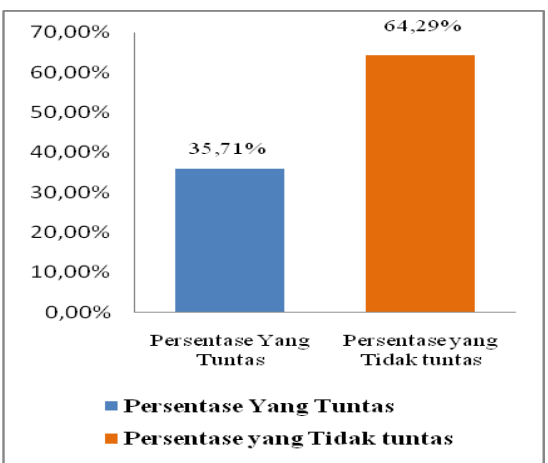

Gambar 6. Grafik Persentase Ketuntasan Klasikal Hasil Belajar Siklus I

\section{Refleksi}

Setelah menyelesaikan pembelajaran dan membuat tes hasil belajar untuk siklus 1 dibuatlah refleksi terhadap pembelajaran Siklus 1. Hasil refleksi menunjukkan bahwa aktivitas dan hasil belajar peserta didik masih rendah dalam pembelajaran PPKn meskipun ada peningkatan hasil belajar dengan nilai peningkatan yang tidak signifikan. Kecilnya peningkatan ini disebabkan oleh faktor kurangnya motivasi dan pemahaman peserta didik dalam hal proses dan pendekatan yang dilaksanakan. Dengan demikian guru perlu melakukan perbaikan pembelajaran pada siklus 2. Guru juga harus lebih banyak 
memberikan motivasi kepada peserta didik agar tetap semangat dalam mengikuti proses pembelajaran dengan model Time Token.

\section{Siklus II}

\section{Perencanaan}

Peneliti bersama guru kelas V/A berdiskusi untuk membuat perbaikan atas kekurangan yang ditemukan dalam kegiatan pembelajaran di siklus I. Perbaikan dilakukan pada RPP, menyiapkan alat-alat yang akan digunakan dalam pelaksanaan penelitian seperti Rencana Pelaksanaan Pembelajaran (RPP), Lembar Kerja (LKS), panduan observasi aktivitas guru dan peserta didik, media yang akan digunakan sesuai dengan model pembelajaran dan materi pembelajaran tentang tentang sikap-sikap yang sesuai dengan nilai-nilai yang terkandung dalam sila Pancasila.

\section{Pelaksanaan}

Peneliti melakukan penelitian siklus II pada hari Senin tanggal 30 Juli 2019. Pada tahap pelaksanaan Siklus II ini, peneliti melaksanakan kegiatan pembelajaran dengan mengacu pada tahapan kegiatan pembelajaran model Time Token. Kegiatan yang dilakukan mengikuti tahapan pembelajaran siklus I, dengan beberapa pembenahan berupa penjelasan kepada peserta didik tentang mekanisme pembelajaran dengan model Time Token, memberikan motivasi secara berulangulang pada setiap kegiatan pembelajaran, memberikan kesimpulan dan penegasan tentang materi pembelajaran sebelum dibuat evaluasi.

\section{Pengamatan}

Hasil pengamatan terhadap aktivitas peserta didik dalam proses pembelajaran siklus II menunjukkan adanya peningkatan nilai aktivitas peserta didik menjadi 85,18 dengan kategori sangat tinggi. Nilai aktivitas peserta didik mengalami peningkatan yang sangat signifikan dengan angka peningkatan sebesar 30,94. Nilai aktivitas belajar tersebut dapat dilihat pada grafik berikut:

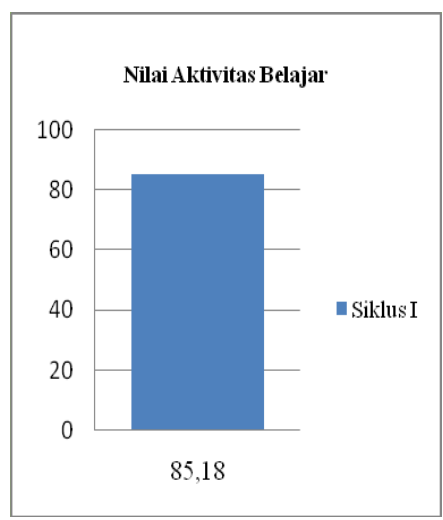

Gambar 7. Grafik Nilai Aktivitas Belajar Peserta Didik Siklus II

Peningkatan juga terjadi pada aktivitas guru siklus II di mana nilai aktivitas gurunya adalah 88,33 . Nilai ini masuk dalam kategori sangat tinggi. Nilai aktivitas guru mengalami peningkatan sebesar 21,66. Nilai aktivitas guru pada siklus II terlihat pada grafik berikut:

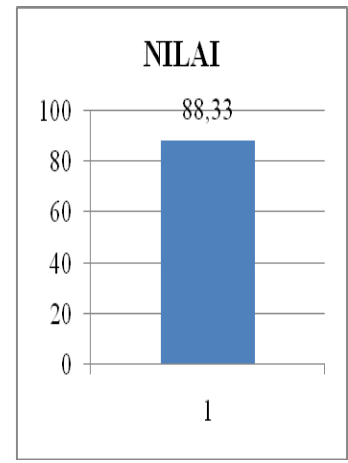

Gambar 8. Grafik Nilai Aktivitas Guru Siklus II

Selain terjadi peningkatan nilai aktivitas pada peserta didik dan guru, pelaksanaan siklus 2 juga menunjukkan adanya peningkatan pada hasil belajar setelah menggunakan model Time Token. Persentase ketuntasan klasikal 
hasil belajar peserta didik adalah $100 \%$. Semua peserta didik telah mengalami ketuntasan hasil belajar. Nilai tertinggi hasil belajar adalah 100 dan nilai terendah 85 dengan rata-rata kelas pada siklus II sebesar 99,28. Persentase ketuntasan klasikal tersebut masuk dalam kategori sangat tinggi. Persentase ketuntasan klasikal hasil belajar peserta didik pada siklus II terlihat pada grafik berikut:

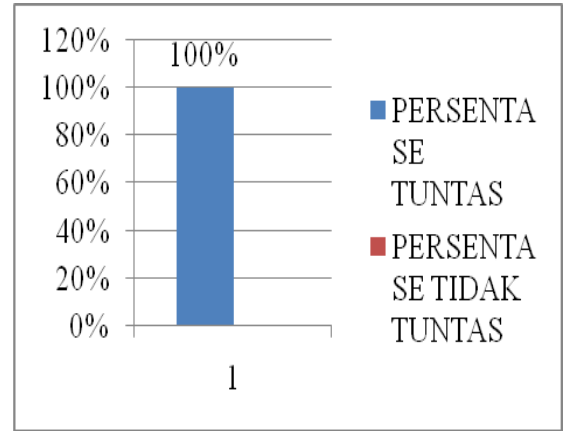

Gambar 9. Grafik Persentase Ketuntasan Klasikal Hasil Belajar Siklus II

\section{Refleksi}

Refleksi atas pelaksanaan pembelajaran pada siklus II menunjukkan adanya fakta sebagai berikut: peserta didik begitu antusias dan senang mengikuti proses pembelajaran, peserta didik telah berani menjawab dan aktif dalam menyelesaikan diskusi sesuai instrukis dalam LKS, peserta didik berani untuk menyampaikan hasil pekerjaannya di depan kelas. Hasil tes hasil belajar siklus II menunjukkan bahwa semua peserta didik telah tuntas dengan rata-rata nilai yang sangat tinggi, sehingga tidak perlu perlu dilanjutkan ke siklus berikutnya.

\section{Penerapan Model Pembelajaran Time Token pada Pembelajaran PPKn Kelas V SD GMIT Ende 4}

Pembelajaran yang berkualitas adalah pembelajaran yang ditandai adanya keterlibatan yang aktif dan keberhasilan belajar dari peserta didik sesuai standar kompetensi yang ditetapkan. Indikator keterlibatan yang aktif dari peserta didik antara lain: peserta didik memberikan perhatian yang sungguh terhadap proses pembelajaran yang sedang berlangsung, aktif bertanya dan memberikan pendapat sesuai dengan pengetahuan dan kemampuan yang dimilikinya. Indikator keberhasilan belajar terlihat pada hasil yang dicapai peserta didik setelah menyelesaikan pembelajaran dalam bentuk nilai pengetahuan, sikap dan karakter yang terbentuk, serta tindakan/perbuatan sebagai implementasi dari pengetahuan dan karakternya.

Pembelajaran dengan model Time Token memberikan jawaban atas tuntutan pembelajaran berkualitas tersebut. Dengan pembelajaran menggunakan model Time Token dalam pembelajaran PPKn, guru dapat menerapkan pembelajaran yang menyenangkan, mengesankan dan dapat memicu partisipasi aktif peserta didik, sehingga terlatih untuk belajar mandiri, aktif, dan kreatif (Huda, 2013: 239). Pada model pembelajaran Time Token peserta didik dipacu dan termotivasi untuk lebih aktif selama proses pembelajaran, terjadi pemerataan peran dalam pembelajaran tanpa ada peserta didik yang mendominasi dan ada yang diam saja. Time Token adalah struktur yang dapat digunakan untuk mengajarkan keterampilan sosial dan berpartisipasi agar menghindari peserta didik mendominasi pembicaraan atau peserta didik diam sama sekali (Wulan, dkk., 2016). Model pembelajaran ini dapat mengatasi permasalahan dengan kondisi peserta didik di kelas yang kurang aktif selama pembelajaran berlangsung, baik dalam 
diskusi kelompok maupun klasikal. Model Time Token sangat tepat digunakan dalam pembelajaran karena dapat melatih keterampilan sosial peserta didik, guna memberikan dorongan kepada peserta didik untuk lebih aktif berbicara bagi peserta didik yang bersikap diam selama proses pembelajaran.

Pendapat-pendapat yang diuraikan di atas, terbukti nyata dalam pembelajaran PPKn kelas V SD GMIT Ende 4 yang telah dilakukan. Dalam pembelajaran terdapat fakta terjadinya peningkatan aktivitas peserta didik dari yang semula diam dan kurang aktif. Model pembelajaran Time Token telah membuat peserta didik sangat antusias dan senang mengikuti proses pembelajaran, peserta didik berani mengungkapkan pendapatnya untuk menjawab pertanyaan guru, aktif dalam melaksanakan tugasnya sesuai instruksi dalam LKS. Peserta didik berani untuk menyampaikan hasil pekerjaannya di depan kelas. Antusisme dan keberanian ini terbukti di dalam pengukuran terhadap nilai aktivitas belajar peserta didik pada siklus I dan II. Pada siklus I nilai aktivitas peserta didik adalah 54,24 dengan kategori rendah dan pada siklus 2 menjadi 85 , 18 dengan kategori sangat tinggi.

Selain aktivitas belajar peserta didik yang menunjukkan nilai optimal, aktivitas guru pun mengalami peningkatan. Pada siklus I nilai aktivitas guru mencapai angka 66,67 dan pada siklus II meningkat menjadi 88,33 . Hal ini menunjukkan bahwa pada siklus II guru telah sungguh-sungguh menerapkan model pembelajaran Time Token secara baik. Kekurangan-kekurangan yang terjadi pada siklus I telah diperbaiki sehingga pembelajaran pada siklus II terlaksna secara maksimal. Dengan demikian dapat dikatakan bahwa model pembelajaran Time Token pada pembelajaran PPKn kelas V SD GMIT Ende 4 telah diterapkan dengan baik sehingga nilai aktivitas guru masuk kategori sangat tinggi dan peningkatan aktivitas peserta didik sebagaimana yang diidealkan dalam pembelajaran dengan model Time Token sungguh-sungguh terwujud.

\section{Hasil Belajar PPKn pada Peserta Didik Kelas V Setelah Diterapkan Model Pembelajaran Time Token}

Ada beberapa aspek yang dapat dianalisis dan dibahas berkaitan dengan hasil penelitian tindakan yang telah dilaksanakan. Aspek-aspek itu antara lain: analisis orientasi awal, analisis situasi sosial sekolah, analisis karakteristik guru dan peserta didik, analisis awal pembelajaran, analisis pelaksanaan tindakan dan analisis keterbatasan penelitian. Meski demikian, pembahasan pada bagian ini hanya difokuskan pada analisis hasil belajar PPKn pada peserta didik kelas V SD GMIT Ende 4 setelah siterapkannya model Time Token.

Hasil belajar secara sederhana dapat diartikan sebagai pencapaian dari peserta didik setelah menyelesaikan suatu pembelajaran. Ada pencapaian yang dilihat pada pengetahuan dan pemahaman, dan ada pula yang diukur pada pembentukan sikap dan keterampilan. Sudjana menyatakan bahwa hasil belajar pada hakekatnya adalah perubahan tingkah laku seseorang yang mencakup kemampuan kognitif, afektif, dan psikomotor setelah mengikuti suatu proses belajar mengajar tertentu (Sudjana, 2009: 3). Dalam konsep yang lebih sempit, hasil belajar sering dipahami sebagai hasil evalausi 
terhadap pemhaman peserta didik akan materi pembelajaran setelah menyelesaikan suatu proses pembelajaran. Baik buruk atau tinggi rendahnya hasil belajar ditentukan oleh nilai yang diperoleh peserta didik setelah menjalani tes atau evaluasi pembelajaran.

Berdasarkan data hasil penelitian tindakan yang telah dilakukan sebanyak 2 siklus pada pembelajaran PPKn di kelas V SD GMIT Ende 4 dapat dikatakan bahwa model Time Token sangat efektif dalam meningkatkan hasil belajar peserta didik kelas V dalam pembelajaran PPKn. Pernyataan ini dibuktikan dengan adanya peningkatan hasil belajar yang sangat signifikan mulai dari hasil pretest hingga hasil belajar pada siklus II. Hasil pretest yang dibuat sebelum terlaksnanya tindakan menunjukkan bahwa nilai rata peserta didik dalam pembelajaran PPKn hanya mencapai angka 53,57 dengan persentase ketuntasan klasikal sebesar $21,43 \%$. Persentase ketuntasan ini masuk dalam kategori rendah. Setelah dilaksanakan pembelajaran dengan model Time Token pada siklus I, hasil belajar yang diperoleh peserta didik mengalami peningkatan dengan nilai rata-rata 69,64 dan persentase ketuntasan klasikal sebesar 35,71. Itu berarti pada siklus I terjadi peningkatan nilai rata-rata sebesar 16,07 , sementara untuk persentase ketuntasan klasikal terjadi peningkatan sebesar $14,28 \%$. Selanjutnya pada siklus II hasil belajar peserta didik kelas V dalam pembelajaran PPKn juga mengalami peningkatan dari perolehan pada siklus I. Pada siklus II, nilai rata-rata hasil belajar peserta didik adalah 99,28 dan persentase ketuntasan klasikal 100\%. Terjadi peningkatan nilai rata-rata dari siklus I sebesar 29,64 dan peningkatan persentase ketuntasan sejumlah 64,29\%. Tabel dan grafik peningkatan hasil belajar dijabarkan di bawah ini:

Tabel 3

Nilai Rata-Rata Hasil Belajar Pra-Tindakan, Siklus I dan Siklus II

\begin{tabular}{cccc}
\hline No & Pra tindakan & Siklus I & Siklus II \\
\hline $\mathbf{1}$ & 53,57 & 69,64 & 99,28 \\
\hline
\end{tabular}

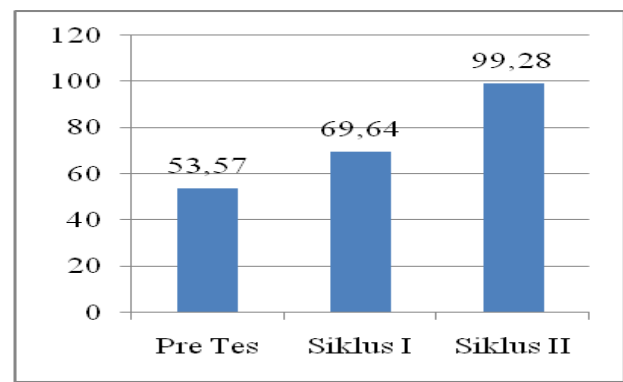

Gambar 11. Grafik Nilai Rata-Rata Hasil Belajar Pra Tindakan, Siklus I dan Siklus II

Tabel 4

Persentase Ketuntasan Klasikal Pra Tindakan, Siklus I dan Siklus II

\begin{tabular}{cccc}
\hline No & Pra tindakan & Siklus I & Siklus II \\
\hline $\mathbf{1}$ & $21,43 \%$ & $35,71 \%$ & $100 \%$ \\
\hline
\end{tabular}

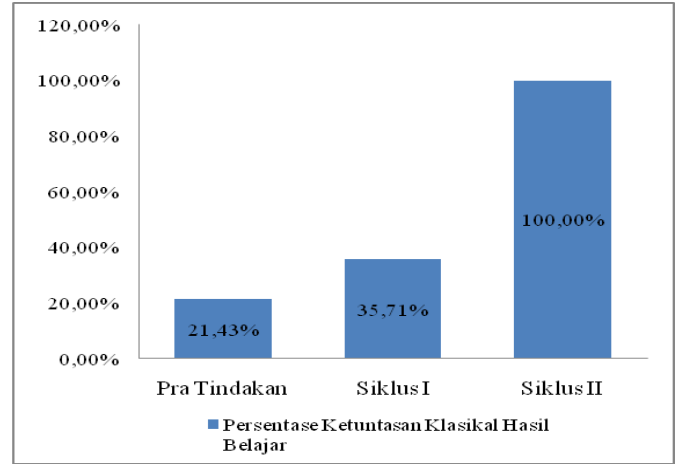

Gambar 12. Grafik Persentase Ketuntasan Klasikal Hasil Belajar Pra Tindakan, Siklus I dan Siklus II

Peningkatan hasil belajar dalam bentuk persentase ketuntasan klasikal dan nilai ratarata hasil belajar PPKn di SD GMIT menunjukkan bahwa model Time Token merupakan model yang tepat dan efektif untuk memperbaiki hasil pembelajaran PPKn di kelas V SD GMIT Ende 4. Temuan dalam penelitian ini sejalan dengan temuan yang telah dipublikasikan dengan kesimpulan 
bahwa model Time Token dapat memperbaiki masalah ketidakaktifan dan rendahnya hasil belajar peserta didik. Nurfirdaus dan Munandar (2018) menemukan bahwa penerapan model Time Token dapat meningkatkan hasil belajar Ilmu Pengetahuan Sosial (IPS) kelas V SD Negeri Pajambon; Windi, dkk (2015) menemukan bahwa model Time Token efektif untuk meningkatkan pemahaman konsep Matematika pada siswa kelas IV SDN Kedungrejo 02 Tunjungan Blora; Nardiani, dkk. (2015) menemukan bahwa model Time Token dapat meningkatkan kemampuan bertanya dan hasil belajar mata pelajaran Ekonomi di kelas X IIS 4 SMA 1 Batu; Utami, dkk. (2016) menyimpulkan bahwa model Time Token dengan media photo story dapat meningkatan keterampilan bercerita pada siswa kelas IV B SD Negeri 2 Kebandongan tahun ajaran 2015/2016; Sari dan Usmadi (2017) menemukan bahwa hasil belajar matematika peserta didik VIII SMP N 1 Padangpanjang setelah penerapan model pembelajaran kooperatif tipe Time Token disertai pemberian kuis lebih baik dari pada hasil belajar matematika peserta didik yang tidak menerapkan; Rahman, dkk. (2017) menemukan bahwa model Time Token dapat meningkatkan hasil belajar Bahasa Indonesia siswa kelas V SDN 200 Lompu Kecamatan Cina Kabupaten Bone; Marfuatun, dkk. (2014) menyimpukan bahwa model pembelajaran Time Token dapat meningkatkan aktivitas belajar Sejarah siswa kelas Xa SMA Negeri 1 Seputih Mataram. Dengan demikian dapat disimpulkan bahwa model Time Token adalah model pembelajaran ideal untuk mengatasi problem rendahnya aktivitas dan hasil belajar peserta didik. Jika model
Time Token digunakan maka aktivitas dan hasil belajar peserta didik akan meningkat sesuai dengan harapan. Pendapat Arends (1998:37) yang menyatakan bahwa model pembelajaran Time Token dapat memberikan ruang bagi masing-masing anggota kelompok diskusi untuk memberikan konstribusi dalam menyampaikan pendapat mereka dan mendengarkan pandangan serta pemikiran anggota lain, sesungguhnya telah terwujud dan memberikan kontribusi bagi peningkatan hasil belajar peserta didik secara klasikal.

\section{SIMPULAN DAN SARAN}

\section{Simpulan}

Penelitian Tindakan Kelas ini dilaksanakan pada SD GMIT Ende 4 Kecamatan Ende Utara Kabupaten Ende. Berdasarkan penelitian yang telah dilakukan, dapat dirumuskan kesimpulan, antara lain:

1. Model pembelajaran Time Token telah diterapkan guru dengan baik di dalam pembelajaran PPKn. Hal itu dapat dilihat pada substansi RPP yang disusun dan aktivitas pembelajaran yang telah dilakukan sesuai dengan langkah-langkah yang tepat sesuai petunjuk umum dalam kegiatan pembelajaran. Nilai aktivitas guru menunjukkan angka dengan kategori tinggi. Nilai aktivitas guru siklus I Aktivitas pembelajaran peserta didik juga baik meskipun membutuhkan perbaikan sejak siklus I hingga siklus II. Pada siklus I nilai aktivitas guru mencapai angka 66,67 dan pada siklus II meningkat menjadi 88 , 33. Pada siklus I nilai aktivitas peserta didik adalah 54,24 dengan kategori rendah dan pada siklus 2 menjadi 85,18 dengan kategori sangat tinggi. 
2. Tejadi peningkatan hasil belajar PPKn pada peserta didik kelas V SD GMIT Ende 4 setelah diterapkan model pembelajaran Time Token. Nilai rata-rata hasil belajar pada saat pre-test adalah 53,57, meningkat menjadi 69,64 pada siklus I dan 99,28 pada siklus II. Persentase ketuntasan klasikal hasil belajar pre-test sebesar 21,43\%, meningkat menjadi $35,71 \%$ pada siklus I dan $100 \%$ pada siklus II.

\section{Saran}

Mempertimbangkan simpulan yang telah dirumuskan, maka peneliti memberikan saran sebagai berikut:

1. Guru diharapkan mengurangi metode/model pembelajaran yang monoton, menjenuhkan dan terpusat pada guru sehingga peserta didik dapat terlibat secara aktif dalam pembelajaran;

2. Guru yang mengalami problem pembelajaran berupa rendahnya aktivitas dan hasil belajar peserta didik, dapat menerapkan model Time Token untuk mengatasi problem tersebut, sambil dikombinasikan dengan media atau alat peraga tertentu agar pembelajaran lebih manrik dan menyenagkan bagi peserta didik.

\section{DAFTAR PUSTAKA}

Arikunto, Suharsimi, 2010. Prosedur Penelitian. Jakarta: PT. Rineka Cipta, 2010.

Huda Miftahul. Model-Model Pengajaran dan Pembelajaran. Yogyakarta: Pustaka Pelajar, 2013.

Istarani. Model Pembelajaran Inovatif, Referensi Guru Dalam Menentukan Model Pembelajaran. Medan: Penerbit Media Persada, 2011.
Junedi dan Anggiani, "Penggunaan Model Pembelajaran Time Token Terhadap Pemahaman Konsep Matematika Siswa Kelas Viii Smp", MES (Journal of Mathematics Education and Science), Vol. 4, No. 1. Oktober 2018, Universitas Islam Sumatera Utara.

Marfuatun, dkk., "Pengaruh Model Pembelajaran Time Token Terhadap Aktivitas Belajar Sejarah Siswa Kelas X Pesagi”. Jurnal Pendidikan Dan Penelitian Sejarah. Vol 2, No. 2 Tahun 2014. Universitas Lampung.

Mauliza, dkk. "Pengaruh Model Pembelajaran Kooperatif Tipe Time Token Arends terhadap Hasil Belajar Siswa Pada Materi Sistem Pernapasan di Sma Negeri 5 Banda Aceh", Jurnal Ilmiah Mahasiswa Pendidikan Biologi, Volume 1, Issue 1, Agustus 2016, Universitas Syiah Kuala, Aceh.

Nardiani, dkk. "Penerapan pembelajaran Model Time Token Arends untuk Meningkatkan Kemampuan Bertanya dan Hasil Belajar Mata Pelajaran Ekonomi di Kelas X IIS 4 SMA 1 Batu, JPE-Volume 8, Nomor 2, 2015, Universitas Negeri Malang

Nurfirdaus dan Munandar, "Penerapan Model Time Token Untuk Meningkatkan Hasil Belajar Ilmu Pengetahuan Sosial (IPS) Kelas V SD Negeri Pajambon", JURNAL LENSA PENDAS, Volume 3 Nomor 2, September 2018, STKIP Muhamadiah Kuningan.

Rahman, dkk. "Penerapan Model

Pembelajaran Time Token Dalam

Meningkatkan Hasil Belajar Bahasa Indonesia Siswa SDN 200 Lompu Kecamatan Cina Kabupaten Bone". JIKAP PGSD: Jurnal Ilmiah Ilmu Kependidikan Vol,1. No.1. Tahun 2017, Universitas Negeri Makassar. 
Sanjaya Wina. Strategi Pembelajaran.

Jakarta. Kencana Prenadamedia Group, 2014.

Sari dan Usmadi. "Penerapan Model Pembelajaran Kooperatif Tipe Time Token Disertai Pemberian Kuis dalam Pembelajaran Matematika.AULADUNA: Jurnal Pendidikan Dasar Islam Vol. 4 No. 2, December 2017, Universitas Islam Negeri Alauddin Makassar.

Silberman Mel. Active Learning. Yogyakarta: Pustaka Insan Mandiri, 2009.

Sudjana, Nana dan Ibrahim, Penelitian dan Penilaian Pendidika. Bandung: Sinar Baru Algesindo, 2009.

Sukmayati, “ Improving Speaking Ability of The Eleventh Year Students of Sma Laboratorium Unsyiah Banda Aceh By Using Time Token Arends Technique". Getsempena English Education Journal (GEEJ) Vol 1, No 2 tahun 2014, STKIP Bina Bangsa Getsempena Banda Aceh

Suprijono, A. Cooperative Learning: Teori dan Aplikasi PAIKEM. Yogyakarta: Pustaka Pelajar, 2013.

Utami,dkk. "Penerapan model Time Token dengan Media Photo Story untuk Meningkatan Keterampilan Bercerita pada Siswa Kelas IV B SD Negeri 2 Kebandongan Tahun ajaran 2015/2016." Jurnal KALAM CENDEKIA, Volume 4, Nomor 6. 1, Universitas Negeri Sebelas Maret.

Windi, dkk. "Keefektifan Model Time Token terhadap Pemahaman Konsep Matematika pada Siswa Kelas IV SDN Kedungrejo 02 Tunjungan Blor" Jurnal Sekolah (JS). Vol 2 (4) September 2018, Universitas Negeri Medan. 